\title{
Midgut volvulus after laparoscopic appendectomy
}

\author{
Volvo de intestino delgado após apendicectomia laparoscópica
}

\author{
Maurício Macedo ${ }^{1}$, Manoel Carlos Prieto Velhote ${ }^{2}$
}

\begin{abstract}
The authors report a case of a 13-year old child who was submitted to a laparoscopic appendectomy and developed, during the postoperative period, an intestinal obstruction caused by small bowel volvulus in the absence of a congenital malrotation.
\end{abstract}

Keywords: Laparoscopy; Appendectomy; Intestinal volvulus; Intestinal obstruction; Pneumoperitoneum; Case reports

\section{RESUMO}

Relato do caso de uma criança de 13 anos de idade submetida à apendicectomia laparoscópica e que, no pós-operatório, desenvolveu quadro de obstrução intestinal, decorrente de um volvo de intestino delgado, na ausência de má rotação intestinal.

Descritores: Laparoscopia; Apendicectomia; Volvo intestinal; Obstrução intestinal; Pneumoperitônio; Relatos de casos

\section{INTRODUCTION}

The use of laparoscopic surgery since its introduction is increasing in all specialties and ages. Patients submitted to laparoscopic surgery when compared with those treated by open surgery have less pain, low complication rates (mainly related to the surgical site), less postoperative ileus, better functional and esthetic results, besides shorter hospital length of stay ${ }^{(1)}$. However, new and rare complications related to this procedure have been reported. Here, we describe a case of midgut volvulus in the absence of malrotation and previous surgeries.

\section{CASE REPORT}

A 13-year-old boy with abdominal pain for 2 days, nausea, vomiting and fever was admitted to our hospital.
He did not show signs of peritoneal irritation on the right iliac fossa. The ultrasound examination showed that the appendix was thick and not compressible. The patient's condition was diagnosed as acute appendicitis, which was confirmed by laparoscopy, and appendectomy was performed. In the first postoperative day the patient complained of a little abdominal discomfort. As symptoms remained unchanged an ultrasonography was performed and revealed gaseous bloating and absence of free peritoneal fluid. On the second postoperative day there was a worsening of symptoms and in the general health status. A computed tomography was performed and showed loop distension and a large amount of free fluid.

A diagnostic laparoscopy showed ischemic bowel loops and was followed by an exploratory laparotomy. The surgical finding consisted of volvulus of the terminal ileum with necrosis along $100 \mathrm{~cm}$ of the small intestine (Figures $1 \mathrm{~A}$ and B). The necrotic bowel was then resected and an entero-entero-anastomosis was done. In the postoperative period the patient evolved without intercurrences.

\section{DISCUSSION}

Most of small bowel volvulus cases happen in the neonatal period due to intestinal malrotation. Volvulus blocks blood flow and leads to ischemia followed by necrosis. It can affect older children and adults as a late manifestation of malrotation ${ }^{(2,3)}$ or from complication of a previous surgery, as an adherence or stoma may act as an axis around which the twisting occurs ${ }^{(4)}$.

Volvulus occurring in the absence of malrotation and previous surgeries in patients submitted to laparoscopic surgery is rare, and few cases have

\footnotetext{
'Hospital Albert Einstein - HIAE, São Paulo (SP), Brazil; Pediatric Surgery Service, Hospital Infantil Darcy Vargas, São Paulo (SP), Brazil.

2 Instituto da Criança, Hospital das Clínicas, Faculdade de Medicina, Universidade de São Paulo - USP, São Paulo (SP), Brazil.

Corresponding author: Maurício Macedo - Avenida Albert Einstein, 627, bloco A1, $2^{\circ}$ andar, conjunto 223 - Morumbi - Zip code: $05651-901$ - São Paulo (SP), Brazil - Phone.: (11) 2151-5223 E-mail:mmmacedo@uol.com.br

Received on: Sep 9, 2011 - Accepted on: Fev 9, 2012
} 


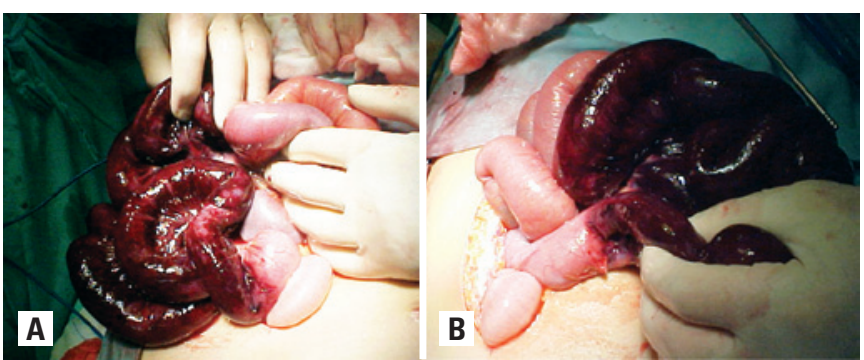

Figure 1 A and B: Intraoperative ischemia and intestinal necrosis

been recently reported. A case of an adult was firstly reported by Caudra ${ }^{(5)}$ in 2002, and Henriques ${ }^{(6)}$ was the first to describe volvulus in children in 2007. A review of the literature was published by Ferguson ${ }^{(7)}$ in 2008 reporting 12 cases of adults, in which 8 were submitted to cholecystectomy, 3 to appendectomy and one to liver biopsy. From these 12 patients, 7 had midgut volvulus, 4 cecal volvulus and one sigmoid volvulus. Of the 7 patients with small bowel volvulus, 3 had intestinal malrotation.

The mechanism of the intestinal volvulus occurrence in laparoscopy procedures is unknown. It is believed that a pneumoperitoneum associated to an abnormal movement and handling of the bowel may speed up the clinical picture. The lateral inclinations of the operating table also seem to contribute to it. Stasis and intestinal bloating because the use of anesthetic drugs and tissue hypoperfusion might be considered potential predisposing factors ${ }^{(7)}$.

To diagnose volvulus at the end of a procedure may be difficult, which requires a constant surveillance. It is also possible that volvulus happens during decompression at the end of the procedure when $\mathrm{CO}_{2}$ is released. Perhaps, a slow decompression might reduce the risk.

\section{REFERENCES}

1. Yeh CC, Wu SC, Liao CC, Su LT, Hsieh CH, Li TC. Laparoscopic appendectomy for acute appendicitis is more favorable for patients with comorbidities, the elderly, and those with complicated appendicitis: a nationwide populationbased study. Surg Endosc. 2011;25(9):2932-42.

2. Arbell D, Koplewitz, Zamir G, Bala M. Midgut volvulus following laparoscopic gastric banding - a rare and dangerous situation. JLAST. 2007:17(3):321-3.

3. Vricella LA, Barrett WL, Tannebaum IR. Intestinal obstruction from midgut volvulus after laparoscopic cholecystectomy. Surg Endosc. 1999;13:1234-5.

4. Lay OS, Tsang TK, Caprini J, Gardner A, Pollack J, Norman E. Volvulus of the small bowel: an uncommon complication after laparoscopic cholecystectomy. JLAST. 1997;7(1):59-62.

5. Cuadra AS, Khalife ME, Char DJ, Wax MR, Halpern D. Intestinal obstruction from midgut volvulus after laparoscopic appendectomy. Surg Endosc. 2002; 16(1):215.

6. Henriques J, Freitas F, Casella P. Midgut volvulus after laparoscopic appendicectomy. Poster 67 presented at the 16th Annual Congress for endosurgery in children; 2007 september 6-8; Buenos Aires, Argentina.

7. Ferguson L, Higgs Z, Brown Sylvia, McCarter D, Mckay C. Intestinal volvulus following laparoscopic surgery: a literature review and case report. JLAST. 2008;18(3):405-10. 